[化 第 42 巻，第 7 号, p. $423 \sim 425,1968$ ]

\title{
桑葉中の微量成分に関する研究（第 7 報）
}

桑葉中よりルチン执よびクエルセチンの単離

内 藤 謙 一

(武田薬品工業株式会社研究開発本部食品研究所)

昭和 42 年 12 月 18 日受理

Studies on the Micro Constituent in Mulberry Leaves

Part VII. Isolation of Rutin and Quercetin from Mulberry Leaves

By Ken-ichi NaITo

Food and Feed Research Laboratories, Research and Development

Division, Takeda Chemical Industries, Ltd.

Seventy $\mathrm{mg}$ of rutin and $4 \mathrm{mg}$ of quercetin were isolated from $1 \mathrm{~kg}$ of dried mulberry leaves. On the feeding test with silkworm larvae, Bombyx mori, quercetin had a little influence upon feeding behavior but rutin none.

(Received December 18, 1967)

緒言

桑葉中のフラボノイド関しては，さきに舆(1)がイ クエルシトリンを単雅し，林屋ら ${ }^{(2)}$ もれを確認した が，それ以外には報告されていない。

筆者は桑葉よりクロロゲン酸(3)を単離したが, その際, 3 種のフラボノイドを得, それらの5ち2個はルチンお よびクエルセチンであることを確認したので報告する。 他の 1 個は続報にゆずる。

ルチンは桑科植物では，イチジク，カラハナソウ(4), ホップ(5)等から単離され，クエルセチンもホップ(6)に存 在することが知られている，古来，桑白皮に血生降下作 用(7 9)があるといわれているが，これがルチンに基つくく るのではないかと推測される。

\section{実 験 $の$ 部}

1. 抽出：桑葉乾燥粉末 $1 \mathrm{~kg}$ 第 1 図の上5に処 理した。

2. 結晶 $\mathbf{A}$ の同定：得られた結晶 $\mathrm{A}$ は次のような性 質を示す。

1) 淡黄色, 針状結晶. 泠水難溶, 熱水, アルコール に可溶.

2) 呈色反応；モーリッシェ反応陽性. 塩化鉄反応陽 性, 暗緑色. $\mathrm{Mg}-\mathrm{HCl}$ 反応陽性, 紅色 ( $\mathrm{Hg}$ の存在下). $\mathrm{Zn}-\mathrm{HCl}$ 反灾陽性, 深紅色.

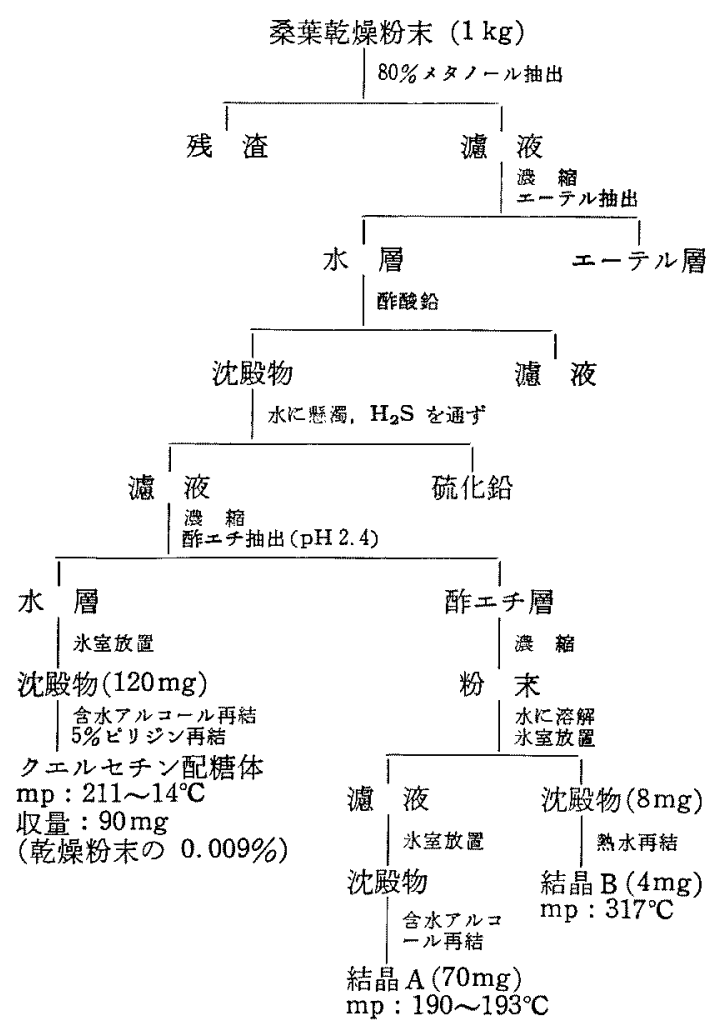

第 1 図 桑葉よりルチン, クエルセチンおよび クエルセチン配糖体の単離 
3) 融点 $190 \sim 193^{\circ} \mathrm{C}$.

4) 紫外部吸収スペタトル；259，363 $\mathrm{m} \mu$ （ケルコー ル) 文触值 $258,361 \mathrm{~m} \mu^{(10)}$

5）比旋光度； $[\alpha]_{\mathrm{D}}^{24^{\circ}}-13.1^{\circ}(c=0.16,50 \%$ アルコ -ル)

6) 赤外線吸収スベクトル； ${ }^{v} c=01655 \mathrm{~cm}^{-1}(\mathrm{KBr})$ 亚品と一政。

7) ペーパークロマトグラフィー；

$$
\begin{array}{ll}
R f=0.49(フ ェ ノ ー ル) & \text { ルチン }=0.49 \\
R f=0.80(60 \% \text { 酢酸 }) & \text { ルチン }=0.80 \\
R f=0.62(n-フ ゙ \text { タール } & : \text { 酿酸 }: \text { 水 }=4: 1: 2) \\
& \text { ルチン }=0.62
\end{array}
$$

索洋濾維 No. $51 \mathrm{~A}$. 一次元上昇法。室温。桱出；1\% 塩化鉄水溶液噴䘑.

8) 元素分析 $\left(\mathrm{C}_{27} \mathrm{H}_{30} \mathrm{O}_{16} \cdot 3 \mathrm{H}_{2} \mathrm{O}\right.$ として $)$ : 実験値 $\mathrm{C}$ 49.07 , H $5.12 \%$, 理論值 C 48.80, H $5.42 \%$.

次に，この結晶を $5 \% \mathrm{H}_{2} \mathrm{SO}_{4}$ で加水分解し，冷却後析 出てる結晶爻滤集し, 濾液は水酸化バリウムで $\mathrm{H}_{2} \mathrm{SO}_{4}$ を 除齐，糖の同定に用いた。

得られた結晶は次の上らな性質を示す。

1) 黄色, 針状結晶.

2)冷水不溶, 熱水, アルコール可溶.

3）呈色反応；モーリッシュ反応陰性．塩化鉄反応陽 性, 暗緑色. $\mathrm{Mg}-\mathrm{HCl}$ 反応陽性, 赤色 $(\mathrm{Hg}$ の存在下). $\mathrm{Zn}-\mathrm{HCl}$ 反応陰性.

4) 融点 $317^{\circ} \mathrm{C}$

5）紫外部吸收スペクトル；257，374 m $\mu$ (アルコー L)

6) 赤外線吸収スペクトル； KBrにてクェルセチン に一致.

7) ペーパークロマトグラフィー；

$$
\begin{aligned}
& R f=0.57 \text { (フェノール) クェルセチン }=0.58 \\
& R f=0.45(60 \% \text { 酶酸) クェルセチン }=0.45
\end{aligned}
$$

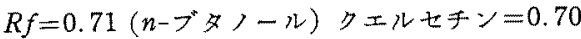

この結晶をアセチル化すると，融点 $193^{\circ} \mathrm{C}$ を示し，市 販のクエルセチンをアセチル化したペンタアセチル・ク エルセチンと混融したところ，融点の降下がみられず, したがって，この結晶をクエルセチンと同定した。

次に濾夜を澧愁し，糖成分を検索した。

$$
\begin{aligned}
& \text { ペーパークロマトグラフィー； } \\
& R f=0.37 \text { および } 0.61 \text { (フェノール) グルニース } \\
& R f=0.38 \text {. ラムノース }=0.65
\end{aligned}
$$

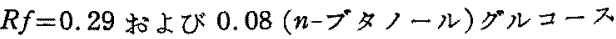

$$
\begin{aligned}
& R f=0.31 \text {, ラムノース }=0.08
\end{aligned}
$$

東洋滤紙 No. 51 A. 一次元上旿法. 室温。

㮝出: アニリンハイドロジェンフタレート液噴麗.

スポットは2佔敛出され，それぞれグルコースおよび ラムノースに一致した。

以上の結果を総合すると，原結晶Aはその理化学的性

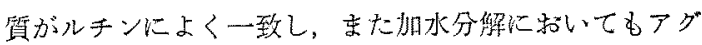
リコンとしてクェルセチンを得, 糖部としてグルコース 和よびラムノースを得るのでルチンに一致する。そこで、 市肘のルチンと混融したととる融点の降下至認めなかっ たのでこの結晶をルチンと同定した。

\section{3. 結晶Bの同定}

得られた結晶Bは次のような性質を示す。

1) 黄色猃状結晶. 冾水雚浴, 熱水, アルコール可溶.

2）呈色反応；ヒーリッシュ反応陰性．塩化鉄反応陽 性, 暗緑舁. $\mathrm{Mg}-\mathrm{HCl}$ 反応陽性, 赤色 $(\mathrm{Hg}$ の存在下). $\mathrm{Zn}-\mathrm{HCl}$ 反応陰性.

3) 融点 $317^{\circ} \mathrm{C}$ decomp.

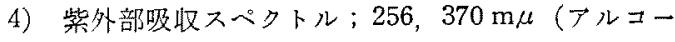
u).

5）赤外線吸収スペクトル； $\mathrm{KBr}$ でクエルもチンに 一致.

6) ペーパークロマトグラフィー；

\begin{tabular}{|c|c|}
\hline 脱脂大豆粉 & $2 \mathrm{~g}$ \\
\hline 菣 & I g \\
\hline 澌 & $1 \mathrm{~g}$ \\
\hline 緎維絜粉末 & $5 \mathrm{~g}$ \\
\hline 寒 天 末 & $0.5 \mathrm{~g}$ \\
\hline ßーシトステリン & $100 \mathrm{mg}$ \\
\hline
\end{tabular}

$$
\begin{array}{ll}
R f=0.75(フ ェ ノ ー ル) & \text { クェルセチン }=0.75 \\
R f=0.45(60 \% \text { 酷酸) } & \text { クェルセチン }=0.46 \\
R f=0.77(n-フ ゙ タ ゙) ー ル) ~ & \text { クェルセチン }=0.77
\end{array}
$$

以上の諸性質かららンルセチンを推定し，市肘のクエ ルセチンと混融したところ，融点の降下を認めなかった ので，結晶Bをクエルセチンと同定した。

4. ルチン, およびクエルセチンの奎児摂食促進効果 の試験：フラボノイドのモリンイソクエルシトリ

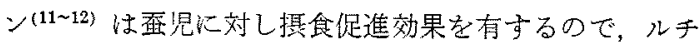
ンおよびクエルセチンの效果をしらべた，基本飼料は次 のと括りである。 


$$
\begin{array}{lr}
\text { ウェッソンズ・ミネラル } & 150 \mathrm{mg} \\
\text { 第二燐酸カリ } & 50 \mathrm{mg} \\
\text { イノシトール } & 50 \mathrm{mg} \\
\text { アスコルビン酸 } & 40 \mathrm{mg} \\
\text { ビタミン B混合物 } & 50 \mathrm{mg} \\
\text { コリンクロライド } & 7 \mathrm{mg} \\
\text { 水 } & 15 \sim 16 \mathrm{cc}
\end{array}
$$

\begin{tabular}{|c|c|c|c|c|c|c|}
\hline 実 & 験 & & $\begin{array}{l}25 \mathrm{mg} / \\
10 \mathrm{~g} \mathrm{diet}\end{array}$ & $\begin{array}{l}50 \mathrm{mg} / \\
10 \mathrm{~g} \text { diet }\end{array}$ & $\begin{array}{l}100 \mathrm{mg} / \\
10 \mathrm{~g} \text { diet }\end{array}$ & $\begin{array}{l}200 \mathrm{mg} / \\
10 \mathrm{~g} \text { diet }\end{array}$ \\
\hline 対 & 照 & \multicolumn{5}{|c|}{$x=56$} \\
\hline ル & f & ข & 54 & 66 & 121 & 56 \\
\hline \multicolumn{3}{|c|}{ クェルセチン } & 72 & 131 & 128 & 117 \\
\hline$モ$ & リ & Y & 272 & 459 & 496 & 354 \\
\hline
\end{tabular}

以上の混合物 $10 \mathrm{~g}$ に効し，ルチン，クエルセチン， モリンをとれぞれ 25，50，100，200 mg 添加し，ギ蛋 10 頭を入れ約 18 時間後の蕒数を数えた。 その結果は次 のよ5であった。

この結果からみて，クエル好チンは少しく掑食促進効 果が認められるが，ルチンは唒とんど效果が認められな い.

\section{要䄪}

（1）桑葉中からルチンおよびクエル七チンを単離・
確認した。

（2）クエルセチンは，在児に対し少しく摂食促進效 果が認められたが，ルチンにはなかった。

最嵝に発表を許可されだ当研究所長由中邦喜博士，畜

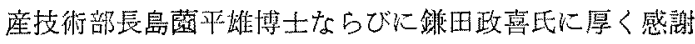
いたします。

（1）奥 正已：農化，10，1029 (1934).

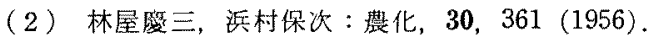

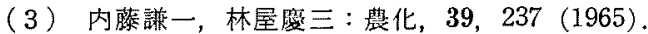

（4）中沖太七郎，森田直蜸，西野真一郎：涾誌，77, 110 (1957).

(5) Y. Umeda and M. Koshihara: Proc. Jap. Acad., 30, 387 (1954).

(6) J.R. Wagner: Jahresber. Chem., 585 (1859).

（7）大石寅造：亘試嶨，59，1 (1941)。

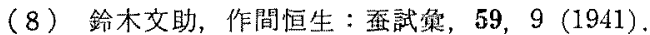

（9）飯野善治：東拻工大学報，p.31（昭 25).

(10) L. Jurd and R. M. Horowitz: J.Org. Chem., 22, 1618 (1957)

(11) Y.Hamamura, K. Hayashiya, K. Naito, K. Matsuura and J. Nishida: Nature, 194, 754 (1962).

（12）林屋度三：日本虫系大会（第36 回）講演要旨集, p. 168 (1966). 